\title{
Life Cycle Assessment (LCA) of an Innovative Compact Hybrid Electrical-Thermal Storage System for Residential Buildings in Mediterranean Climate
}

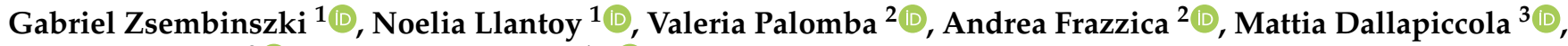 \\ Federico Trentin ${ }^{3}$ (I) and Luisa F. Cabeza ${ }^{1, *}$ (i)
}

1 GREiA Research Group, Universitat de Lleida, Pere de Cabrera s/n, 25001 Lleida, Spain; gabriel.zsembinszki@udl.cat (G.Z.); noelia.llantoy@udl.cat (N.L.)

2 Institute for Advanced Energy Technologies (CNR ITAE), National Council or Research Italy, Salita S. Lucia Sopra Contesse 5, 98126 Messina, Italy; valeria.palomba@itae.cnr.it (V.P.); andrea.frazzica@itae.cnr.it (A.F.)

3 Institute for Renewable Energy, Eurac Research, Viale Druso 1, 39100 Bolzano, Italy; Mattia.Dallapiccola@eurac.edu (M.D.); Federico.Trentin@eurac.edu (F.T.)

* Correspondence: luisaf.cabeza@udl.cat

check for updates

Citation: Zsembinszki, G.; Llantoy, N.; Palomba, V.; Frazzica, A.; Dallapiccola, M.; Trentin, F.; Cabeza, L.F. Life Cycle Assessment (LCA) of an Innovative Compact Hybrid Electrical-Thermal Storage System for Residential Buildings in Mediterranean Climate. Sustainability 2021, 13, 5322. https://doi.org/ $10.3390 /$ su13095322

Academic Editor: Tomonobu Senjyu

Received: 26 March 2021

Accepted: 6 May 2021

Published: 10 May 2021

Publisher's Note: MDPI stays neutral with regard to jurisdictional claims in published maps and institutional affiliations.

Copyright: (c) 2021 by the authors. Licensee MDPI, Basel, Switzerland. This article is an open access article distributed under the terms and conditions of the Creative Commons Attribution (CC BY) license (https:// creativecommons.org/licenses/by/ $4.0 /)$.

\begin{abstract}
The buildings sector is one of the least sustainable activities in the world, accounting for around $40 \%$ of the total global energy demand. With the aim to reduce the environmental impact of this sector, the use of renewable energy sources coupled with energy storage systems in buildings has been investigated in recent years. Innovative solutions for cooling, heating, and domestic hot water in buildings can contribute to the buildings' decarbonization by achieving a reduction of building electrical consumption needed to keep comfortable conditions. However, the environmental impact of a new system is not only related to its electrical consumption from the grid, but also to the environmental load produced in the manufacturing and disposal stages of system components. This study investigates the environmental impact of an innovative system proposed for residential buildings in Mediterranean climate through a life cycle assessment. The results show that, due to the complexity of the system, the manufacturing and disposal stages have a high environmental impact, which is not compensated by the reduction of the impact during the operational stage. A parametric study was also performed to investigate the effect of the design of the storage system on the overall system impact.
\end{abstract}

Keywords: energy storage; heating and cooling system; life cycle assessment (LCA); ReCiPe indicator; global warming potential (GWP) indicator; environmental impact

\section{Introduction}

The building sector is nowadays responsible for a considerable share of worldwide energy consumption, accounting for close to $40 \%$ of the overall energy consumption and associated greenhouse gas emissions to the atmosphere [1]. The prospects are not very hopeful given the current trends of population growth and urbanization, which may lead to an expected growth of $60 \%$ in the built environment by 2050 [2]. Therefore, different energy policies and initiatives at regional, national, and international levels were put in place focusing on the reduction of the environmental impact of the built environment. For instance, European policies aimed in the past few years at a reduction of greenhouse gas emissions to meet previous targets established for 2020 [3] and new targets foreseen for 2030 consisting of a reduction of $40 \%$ of carbon emissions with respect to the levels of 1990 . According to the United Nations [4], sustainable energy production and consumption is one of the goals established to achieve economic growth and sustainable development, and the efficient management of natural resources and the way toxic waste and pollutants are disposed of play an important role in achieving this goal. 
The environmental impact of a building is not only related to its service life, but also to the impact of material and system components corresponding to both manufacturing as well as disposal stages. Life cycle assessment (LCA) is a suitable tool that allows the quantification of a set of environmental impacts associated with the different stages of a given product or service, which can assist in achieving sustainable production and consumption from a global point of view. Results from an LCA can be very useful to a wide range of stakeholders, from manufacturers to policymakers, to help in the decision-making process of a new system or technology from an environmental performance point of view. Therefore, one of the main advantages of an LCA study is that it offers the possibility to identify opportunities for the use of better products, materials, or resources that include all stages of their life cycle. LCA methodology estimates the potential environmental impacts of materials and energy flows during different life cycle phases of a product or process, from "cradle to grave" or "cradle to gate", usually applied in the industrial context [5].

Energy efficiency in buildings has been recognized as a priority objective of energy policies in the built environment, as a way to reduce the impact of economic development and population growth on energy consumption [6]. There are many ways to improve energy efficiency in buildings, such as the integration of renewable energy sources, the implementation of thermal energy storage, the use of innovative technologies and new materials, along with suitable system control and demand-side management. However, an approach for system components' optimization that is only based on energy efficiency or a pinch/exergy analysis is not sufficient to assess the overall environmental impact of a system or component. Ten research topics regarding the improvement of energy and environmental performance of buildings were addressed in the review by Soares at al. [7] towards a more sustainable built environment, which included LCA, thermal storage with phase change materials (PCMs), and the importance of improving the use of renewables, among others.

An approach for the evaluation of the energy efficiency and environmental impacts of a modular and integrated system for renewable electricity generation combined with intelligent electrical storage was presented in [8]. The system allowed for self-production and self-consumption of electricity in residential buildings. The environmental impact along all the life cycle of the system was examined using SimaPro software for three different configurations: (1) a building without production of renewable energy source (RES) and storage, (2) a building with photovoltaic (PV) production without electric storage, and (3) a building with both PV and electric storage. The results showed that the lowest environmental impact was associated with the second system, which had PV production but no storage system. This demonstrated that the storage system had a negative effect in environmental terms, despite providing better results in terms of energy performance indicators, such as self-consumption and self-sufficiency. An LCA methodology was provided by Mousa et al. [9] to assess the environmental impact of three different solar technologies from cradle through the usage phases. Solar thermal collectors, PV panels, and linear Fresnel collector prototype were assessed through a comparative analysis in 12 locations around the world. Different recommendations were provided based on the results, which should serve as a guidance for manufacturers, policymakers, and future standards. A review of LCA on existing electricity generation systems based on renewable energy sources was carried out by Varun et al. [10]. The study concludes that there is a clear favor for renewable energy technologies, although some renewable energy systems, such as solar PV, can have significant life cycle carbon emissions that should be accounted for in evaluating carbon credits available from such systems. An LCA of a central solar heating plants with seasonal storage (CSHPSS) for space heating and domestic hot water supply to 500 dwellings of $100 \mathrm{~m}^{2}$, located in Zaragoza, Spain, was performed by Raluy et al. [11]. The results showed that the auxiliary system had the highest environmental loads despite of covering only $31 \%$ of the heating demand, due to the natural gas consumption. However, the solar subsystem was responsible for a significant NOx and SOx emissions due to the high amount of materials used in the manufacturing phase of the water tank, as 
well as to the electricity consumed in the pumps. The environmental impact of solar collectors was found to be significantly lower. Therefore, techniques and materials with low environmental impact should be used for the manufacturing of seasonal thermal energy storage systems. The integration of hybrid renewable energy systems with electric and thermal energy storage systems was investigated by Bartolucci et al. [12] to identify the optimal configuration of a residential hybrid energy system. A multi-objective analysis that considered costs, renewable energy self-consumption, and emission factors was carried out using a rule-based control strategy to develop an energy management system. By means of an LCA applied to PV and electric storage, the effect of production and disposal emission factors on the sizing of the system was evaluated. The results showed that the inclusion of the TES in the system had a beneficial effect in terms of component sizing and energy efficiency and cost performance indicators.

A review of the existing research on the use of PCM for thermal applications from an environmental perspective, by means of LCA methodology, and economic performance criteria, was carried out by Kyriaki et al. [13]. The LCA analyses were focused on PCM implementation in building envelope as well as in heating and cooling systems. The environmental impact of including PCM in three experimental cubicles with a typical Mediterranean building construction system was assessed by de Gracia et al. [14]. Their results showed that the addition of PCM in the building envelope does not produce a significant reduction of the global impact over the entire lifetime of the building. Castell et al. [15] carried out an evaluation of the environmental impact corresponding to the manufacturing and operation stages of an alveolar brick construction system incorporating PCM. The study concluded that the environmental impact reached thanks to energy savings during the operational stage compensated the higher environmental impact due to the inclusion of PCM in the manufacturing stage. An LCA study based on the EcoIndicator 99 of a ventilated double skin facade with PCM in its air chamber was performed by de Gracia et al. [16]. The environmental impact of the PCM was assessed in comparison to the same system without PCM. The results of the LCA showed that the use of PCM reduced by $7.7 \%$ the environmental impact of the whole building considering a lifetime of 50 years. The study also revealed that the environmental payback of this system is significantly lower than systems that incorporate PCM in the building envelopes. Aranda-Usón et al. [17] applied LCA methodology to determine if the energy savings due to the use of three commercial PCM in buildings located in five different Spanish weather climates compensated the environmental impact of the PCM manufacture and installation. The results showed that the implementation of PCM was able to reduce the overall environmental impacts, and that climate conditions and type of PCM used had a strong influence on that reduction.

A simplified LCA methodology for solar cooling systems with adsorption chillers in different European climates for residential applications was presented by Longo et al. [18]. Their results indicated that the life cycle step with the most impact was the manufacturing stage, whereas during the operational phase, the solar systems outperformed the reference. The useful life of the system proved to be a key parameter and only for at least 15 years of expected lifetime the environmental benefits of using a solar system during the operation step counterbalance the additional impact generated during the other life cycle steps.

The present study analyzes the environmental effects through a comparative LCA of an innovative system aimed at providing cooling, heating, and domestic hot water (DHW) in residential buildings in Mediterranean climate regions. The system includes a heat pump fed by a DC bus connected to a PV system and an electric storage, in cascade with a sorption chiller connected to linear Fresnel collectors to enhance the energy performance of the heat pump. Moreover, an innovative PCM storage is used in the low-pressure side of the heat pump to store the surplus of energy produced during high solar radiation availability. The environmental impacts of the system are compared with a standard system that is used as a reference. 


\section{Methods}

\subsection{Case Study}

An innovative system developed within the EU-funded project HYBUILD was considered in this study. The system was designed with the main purpose to reduce primary energy consumption for cooling supply in Mediterranean climate residential building, although the system also provides heating and DHW. Moreover, a reference system was defined to be able to compare the environmental and energy performance of the innovative system. To achieve this, a unique reference building was used to obtain the different energy demand profiles.

\subsubsection{Reference Building}

The reference building was defined as the most representative building typology for the building stock in Mediterranean climate regions. As such, a single-family house (SFH) located in Athens, in the Attica region in the southeast part of Greece, was considered. The reference building was defined following the common characteristics for a European SFH and consisted of two floors, each having a living surface area of $50 \mathrm{~m}^{2}$, inhabited by four people. The ceiling/floor heights considered were $2.5 \mathrm{~m} / 3.0 \mathrm{~m}$, while the building width/depth were $6.5 \mathrm{~m} / 8.0 \mathrm{~m}$. The glazing ratio was $20 \%$ on the façade facing south, $10 \%$ on the north side, and $12 \%$ on the east and west sides. No balcony was considered, and an overhang due to the roof was considered. A $30^{\circ}$ tilted saddle roof was assumed.

\subsubsection{Reference System}

In addition to defining the reference building, the definition of the reference system was also necessary. This system should serve as a reference for the comparison of the performance of the innovative system. The details of the reference system are given below.

A schematic of the reference system is shown in Figure 1. The system consists of a flat-plate solar collector connected to a water storage tank for DHW production. The DHW storage tank is connected to a gas boiler as a back-up heat supply. Moreover, the gas boiler is also used to meet the heating demand of the reference building.

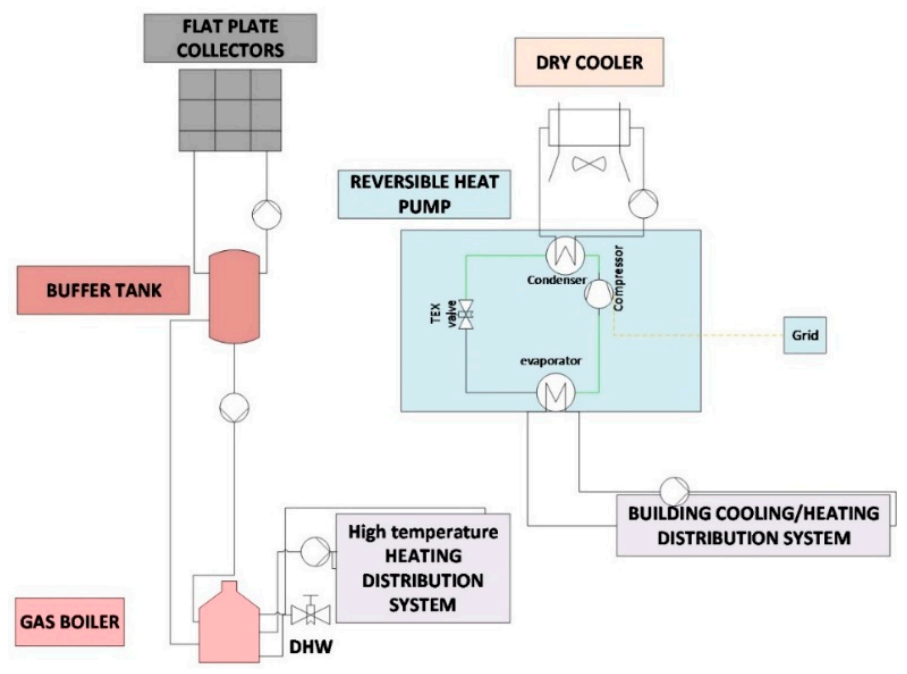

Figure 1. Schematic diagram for the reference system.

The sizing of the main components of the reference system is shown in Table 1 . The values were obtained using a standard approach for component sizing considering the energy demand of the reference building. 
Table 1. Sizing of the main components of the reference system.

\begin{tabular}{cccc}
\hline Component & Variable & Value & Unit \\
\hline Solar collector & Surface area & 1.64 & $\mathrm{~m}^{2}$ \\
DHW storage tank & Storage capacity & 120 & $\mathrm{~L}$ \\
Gas boiler & Maximum thermal power & 25 & $\mathrm{~kW}$ \\
Reversible heat pump & Nominal cooling power & 10 & $\mathrm{~kW}$ \\
\hline
\end{tabular}

\subsubsection{Innovative System}

The diagram of the innovative system is shown in Figure 2. Clearly, the system is more complex than the reference system and it contains a field of lineal Fresnel solar collectors and a PV system to increase the use of renewable energy sources. To improve the energy efficiency of the heat pump working in cooling mode, a sorption chiller is used in cascade with the heat pump $[19,20]$. The heat produced by the Fresnel collectors is used to drive the sorption chiller in summer, but it is also used to contribute to the energy supply for heating and DHW to the building. In addition, the system incorporates a low-temperature PCM thermal energy storage tank and an electric battery to help increase the energy efficiency of the system. A detailed description of system operation is given in [19].

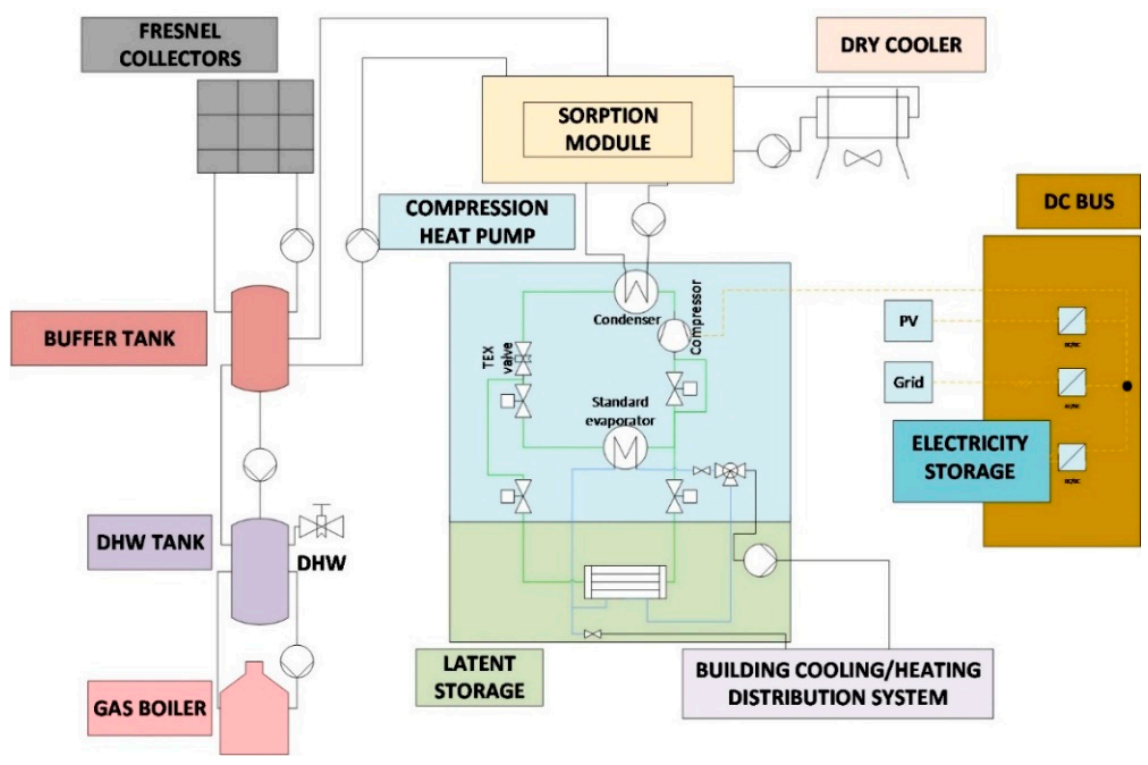

Figure 2. Schematic diagram for the innovative system.

The sizes of some components were fixed according to indications by partners responsible of the specific technology. This is valid for the sensible heat storage (buffer tank), heat pump, and latent heat thermal energy storage. On the other hand, PV nominal power (and consequently PV panel area), electrical storage (battery) capacity, DHW tank volume, and the area of Fresnel solar collectors were sized according to an optimization procedure aiming to maximize the energy-related KPIs of the system. The details of the process have been reported in [21]. As a result of that study, the sizing of the main system components is as shown in Table 2. 
Table 2. Sizing of the main components of the innovative system.

\begin{tabular}{cccc}
\hline Component & Variable & Value & Unit \\
\hline Fresnel solar collectors & Surface area & 60 & $\mathrm{~m}^{2}$ \\
PV panels & Surface area & 20.9 & $\mathrm{~m}^{2}$ \\
Heat pump & Nominal cooling power & 13.2 & $\mathrm{~kW}$ \\
Sensible heat storage (buffer tank) & Storage capacity & 800 & $\mathrm{~L}$ \\
DHW tank & Storage capacity & 250 & $\mathrm{~L}$ \\
Latent heat thermal energy storage & Cooling storage capacity & 12 & $\mathrm{kWh}$ \\
Electrical storage (battery) & Electrical storage capacity & 7.3 & $\mathrm{kWh}$ \\
\hline
\end{tabular}

\subsection{LCA Methodology}

LCA is a methodology that is used to assess the environmental impact of a product over its life cycle. The life cycle of a product or system includes the manufacturing phase (extraction of raw materials, handling, and processing), operational phase (the normal and intended use of the product), and the disposal phase (the end of the product until landfill disposal) [22]. The LCA presented in this study considers a system through its life cycle from cradle to grave.

Commonly, the major focus of using an LCA methodology is on reducing the environmental impact of specific products under consideration for more sustainable solutions through decision-making processes [23]. A full LCA requires significant effort and expertise, although an LCA should at least be performed through four main steps interrelated among them, according to UNE-EN ISO 14040:2006 and ISO 14044 standards [24,25], as is show in Figure 3.

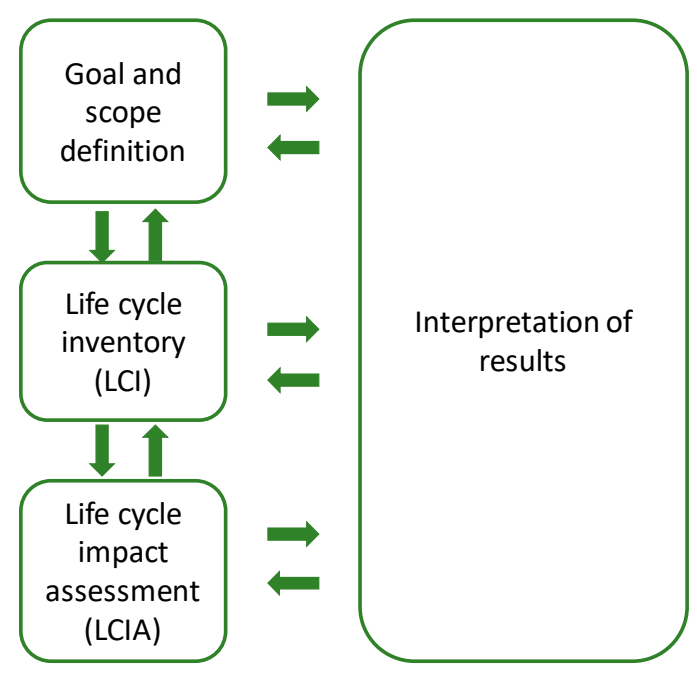

Figure 3. Main steps of the LCA methodology according to ISO 14040. Adapted from [24].

\subsubsection{ReCiPe and GWP Indicator}

The LCA of this study is based on the indicators ReCiPe and Global Warming Potential (GWP), derived from the database Ecoinvent [26]. The ReCiPe indicator, a method used to assess environmental impact, is based on an updated version of CML and Ecoindicator99 [23]. The primary objective of the ReCiPe method is to transform the long list of life cycle inventory results into a limited number of indicator scores. These indicator scores express the relative severity of an environmental impact category. ReCiPe indicators are determined at two levels, eighteen midpoint indicators, and three endpoint indicators. Endpoint indicators show the environmental impact on three higher aggregation levels: effect on human health, biodiversity, and resource scarcity [27]. Converting midpoints to endpoints simplifies the interpretation of the LCA results (Figure 4). 


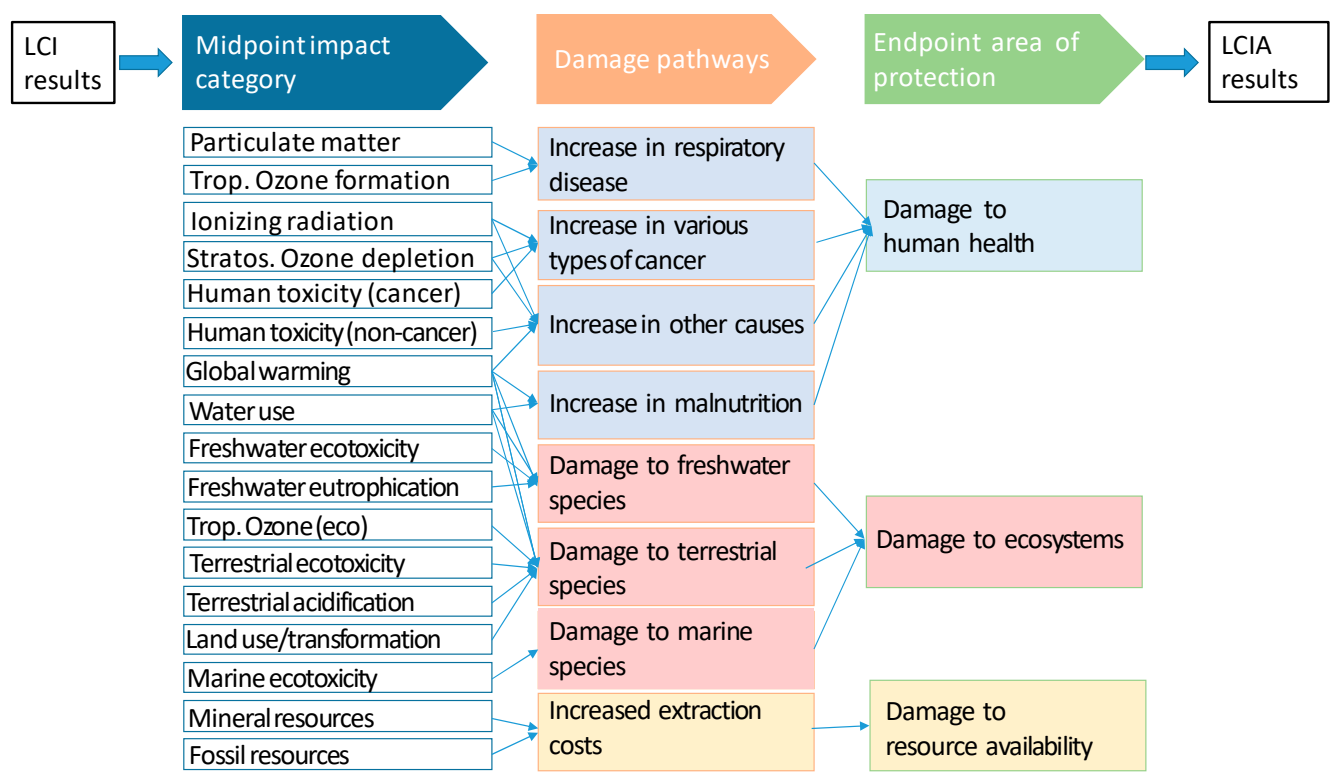

Figure 4. Overview of the impact categories that are covered in the ReCiPe2016 method and their relation to the areas of protection. Adapted from [28].

The IPCC GWP is an indicator based on the ratio of the radiative damage force of greenhouse gases. In order to measure GWP, the gas must have a long atmospheric lifetime, which means that the gas lasts long enough in the atmosphere to mix and spread through it. The selection of the timespan depends on if it is desired to predict the emissions' long-term effect (GWP 100a) or their short-term effect (GWP 20a); the impact of the GWP is measured in $\mathrm{kgCO}_{2}$-eq $[23,29]$.

\subsubsection{Definition of Goal and Scope}

The goal of the LCA study is related to the materials/components development from a sustainable perspective for the intended applications of the innovative system. A benchmark against conventional products was achieved by the use of an equivalent reference system that should provide similar functionalities to the building as the innovative system. Therefore, the main goal of the LCA study is to identify environmental "hot spots" in the life cycle of the most innovative components implemented within the innovative system. This approach should support manufacturers or designers of the relevant components in decision-making processes and product optimization for a future commercial product.

The study presented in this paper focused on the system and not on the building, meaning that only the relevant components of the system were included in the LCA study, with a special focus on the most innovative subsystems. Therefore, the following parts (modules) of the innovative system were considered: sorption storage and dry cooler, low temperature latent heat thermal energy storage (PCM tank), electrical storage and DC bus, compression DC-driven reversible heat pump, solar field of Fresnel collectors, sensible heat storage (buffer tank), and PV system.

\subsubsection{Functional Unit}

The scope of this study was defined according to the performance characteristics of the system under study. The functional unit (FU) must be consistent with the objectives and scope of the system (according to UNE EN ISO 14040 and 14044) [24,25] since it determines the reference flow from which the inputs and outputs of the system are determined. Based on the functional unit, the results of the LCA will be expressed. In this study, the functional unit of $1 \mathrm{~m}^{2}$ of livable floor was adopted, based on publications of LCA studies in the construction sector $[22,23,30]$. A 30-year building lifespan was assumed for this study. Depending on the lifespan of the different components, the number of replacements of 
every component or product during the 30-year period was also calculated, which is a crucial point to be considered in the manufacturing phase.

\subsubsection{System Boundaries}

The study accounts for the raw material extraction to final disposal of the portion of the life cycle and considers embodied environmental impacts. The system boundaries determine which unit processes are included in the LCA study. This approach encompasses three distinct stages of evaluation for each product during its lifetime, and there are different operations in each stage, as shown in Figure 5:

- Manufacturing stage: it refers to materials production phase, including extraction of raw materials, transportation to the factory, and manufacturing processes;

- Operational stage: it refers to all activities related to the use of the systems, including energy consumption for heating, cooling, and DHW production;

- End-of-life stage: it refers to the dismantling and demolishing of the system components, and their transport to the landfill site and/or to recycling sorting plants.
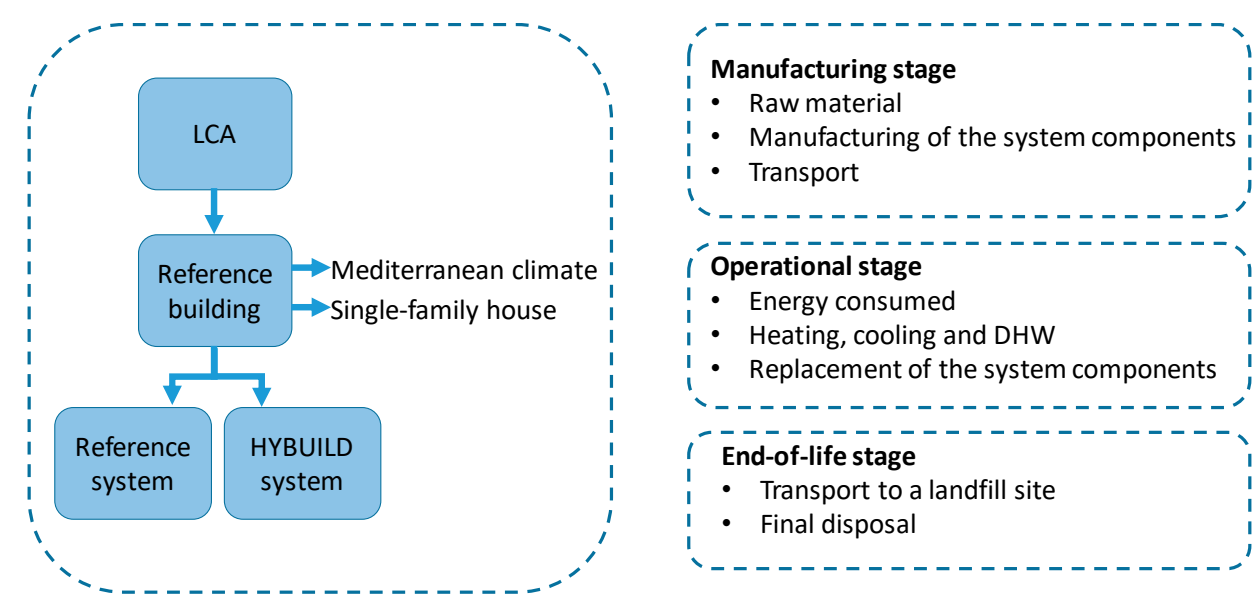

Figure 5. System boundaries of the study.

\subsubsection{Inventory Analysis of the Manufacturing Stage}

The life cycle inventory analysis (LCIA) is defined as a phase of the LCA involving the compilation of inputs and outputs for a given product or system throughout its life cycle [30]. The LCI data was extracted from a recompilation of data provided by different partners of the project. The inventory list of all materials used for the manufacturing stage of the system is shown in Tables 3 and 4 for the reference system and innovative system, respectively.

\subsubsection{Inventory Analysis of the Operational Stage}

The annual energy consumption of the reference system in the reference building was obtained through dynamic simulations carried out in TRNSYS (ref, see comment below). Dynamic simulations are necessary to obtain a realistic evaluation of system behavior along the year, especially for systems in which different parts work together. This is the case of both reference and innovative system considered in this work. Annual energy consumption of the reference system was obtained through simulations carried out in TRNSYS. This variable is needed for the operational stage of the LCA study. Energy consumption of the different system components is summarized in Table 5, where electricity consumption and gas consumption were distinguished because they have a different impact in the operational stage. The values shown in Table 5 correspond to a building set-point temperature of $25^{\circ} \mathrm{C}$ in summer and $20^{\circ} \mathrm{C}$ in winter. 
Table 3. Inventory of reference system.

\begin{tabular}{|c|c|c|c|c|c|c|}
\hline Element & Unit & Quantity/Unit & $\begin{array}{l}\text { Unit of } \\
\text { Measure }\end{array}$ & Replacement & $\begin{array}{c}\text { Total } \\
\text { Amount }\end{array}$ & $\begin{array}{l}\text { Unit of } \\
\text { Measure }\end{array}$ \\
\hline \multicolumn{7}{|c|}{ Solar collector } \\
\hline Solar collector & 1 & 98.5 & $\mathrm{~kg}$ & 1.2 & 118.2 & $\mathrm{~kg}$ \\
\hline 2-way manual valve & 1 & 0.5 & $\mathrm{~kg}$ & 2.5 & 1.3 & $\mathrm{~kg}$ \\
\hline Check valve & 1 & 1.7 & $\mathrm{~kg}$ & 2.5 & 4.2 & $\mathrm{~kg}$ \\
\hline Non-return valve & 1 & 0.4 & $\mathrm{~kg}$ & 2.5 & 1 & $\mathrm{~kg}$ \\
\hline Piping & $7.7(\mathrm{~m})$ & 7.7 & $\mathrm{~kg}$ & 1 & 7.7 & $\mathrm{~kg}$ \\
\hline Insulation (outdoor) & $7.7(\mathrm{~m})$ & 2.3 & $\mathrm{~kg}$ & 1 & 2.3 & $\mathrm{~kg}$ \\
\hline \multicolumn{7}{|c|}{ DHW storage tank } \\
\hline Motorized 3-way valve & 1 & 5 & $\mathrm{~kg}$ & 2.5 & 12.5 & $\mathrm{~kg}$ \\
\hline 2-way manual valve & 4 & 1.8 & $\mathrm{~kg}$ & 2.5 & 4.5 & $\mathrm{~kg}$ \\
\hline Check valve & 1 & 1.7 & $\mathrm{~kg}$ & 2.5 & 4.2 & $\mathrm{~kg}$ \\
\hline Circulation pump & 1 & 1 & unit & 2 & 2 & unit \\
\hline Flow rate display/meter & 1 & 1.2 & $\mathrm{~kg}$ & 1.5 & 1.8 & $\mathrm{~kg}$ \\
\hline Buffer tank & 1 & 1 & unit & 3 & 3 & unit \\
\hline \multicolumn{7}{|c|}{ Gas boiler } \\
\hline Gas boiler & 1 & 1 & unit & 1.5 & 1.5 & unit \\
\hline Piping & $21.3(\mathrm{~m})$ & 21.3 & $\mathrm{~kg}$ & 1 & 21.3 & $\mathrm{~kg}$ \\
\hline Insulation (indoor) & $21.3(\mathrm{~m})$ & 3.8 & $\mathrm{~kg}$ & 1 & 3.8 & $\mathrm{~kg}$ \\
\hline \multicolumn{7}{|c|}{ Heat pump } \\
\hline Heat pump & 1 & 1 & unit & 1.5 & 1.5 & unit \\
\hline 2-way manual valve & 2 & 0.9 & $\mathrm{~kg}$ & 2.5 & 2.2 & $\mathrm{~kg}$ \\
\hline
\end{tabular}

Table 4. Inventory of innovative system.

\begin{tabular}{|c|c|c|c|c|c|c|}
\hline Element & Unit & Quantity/Unit & $\begin{array}{c}\text { Unit of } \\
\text { Measure }\end{array}$ & Replacement & Total Amount & $\begin{array}{c}\text { Unit of } \\
\text { Measure }\end{array}$ \\
\hline \multicolumn{7}{|c|}{ Heat pump } \\
\hline Heat pump & 1 & 1 & unit & 1.5 & 1.5 & unit \\
\hline \multicolumn{7}{|c|}{ Sorption module } \\
\hline Adsorber & 2 & 35 & $\mathrm{~kg}$ & 2 & 140 & $\mathrm{~kg}$ \\
\hline Evaporator & 2 & 18 & $\mathrm{~kg}$ & 2 & 72 & $\mathrm{~kg}$ \\
\hline Bar spacer & 28 & 1.14 & $\mathrm{~kg}$ & 2 & 64 & $\mathrm{~kg}$ \\
\hline Bar spacer (PVC) & 1 & 32 & $\mathrm{~m}$ & 2 & 25 & $\mathrm{~kg}$ \\
\hline Shell & 2 & 23 & $\mathrm{~kg}$ & 2 & 92 & $\mathrm{~kg}$ \\
\hline Perforated metal plate & 2 & 7 & $\mathrm{~kg}$ & 2 & 28 & $\mathrm{~kg}$ \\
\hline Compensator & 4 & 0.3 & $\mathrm{~kg}$ & 2 & 2.4 & $\mathrm{~kg}$ \\
\hline Sealing & 4 & 0.025 & $\mathrm{~kg}$ & 2 & 0.2 & $\mathrm{~kg}$ \\
\hline Vacuum flange & 4 & 0.08 & $\mathrm{~kg}$ & 2 & 0.64 & $\mathrm{~kg}$ \\
\hline Insulation & 2 & 3 & $\mathrm{~kg}$ & 2 & 12 & $\mathrm{~kg}$ \\
\hline Pumps & 3 & 5 & $\mathrm{~kg}$ & 2 & 30 & $\mathrm{~kg}$ \\
\hline 3-way valves & 8 & 0.9 & $\mathrm{~kg}$ & 2 & 14.4 & $\mathrm{~kg}$ \\
\hline Hydraulic tubes & 1 & 25 & $\mathrm{~kg}$ & 2 & 50 & $\mathrm{~kg}$ \\
\hline Insulation & 1 & 4 & $\mathrm{~kg}$ & 2 & 8 & $\mathrm{~kg}$ \\
\hline Base plate & 1 & 62.5 & $\mathrm{~kg}$ & 2 & 125 & $\mathrm{~kg}$ \\
\hline Frame & 1 & 62.5 & $\mathrm{~kg}$ & 2 & 125 & $\mathrm{~kg}$ \\
\hline Shell & 1 & 155 & $\mathrm{~kg}$ & 2 & 310 & $\mathrm{~kg}$ \\
\hline Zeolite & 1 & 22 & $\mathrm{~kg}$ & 2 & 44 & $\mathrm{~kg}$ \\
\hline \multicolumn{7}{|c|}{ Dry cooler } \\
\hline System separation unit & 1 & 45 & $\mathrm{~kg}$ & 2 & 90 & $\mathrm{~kg}$ \\
\hline Heat exchanger and frame & 1 & 561 & $\mathrm{~kg}$ & 2 & 1122 & $\mathrm{~kg}$ \\
\hline Vans & 3 & 10 & $\mathrm{~kg}$ & 2 & 60 & $\mathrm{~kg}$ \\
\hline Electric cables & 10 & 3 & $\mathrm{~kg}$ & 2 & 60 & $\mathrm{~kg}$ \\
\hline
\end{tabular}


Table 4. Cont.

\begin{tabular}{|c|c|c|c|c|c|c|}
\hline Element & Unit & Quantity/Unit & $\begin{array}{l}\text { Unit of } \\
\text { Measure }\end{array}$ & Replacement & $\begin{array}{c}\text { Total } \\
\text { Amount }\end{array}$ & $\begin{array}{l}\text { Unit of } \\
\text { Measure }\end{array}$ \\
\hline \multicolumn{7}{|c|}{ Fresnel collectors } \\
\hline Collector frame & 1 & 875 & $\mathrm{~kg}$ & 1.2 & 1050 & $\mathrm{~kg}$ \\
\hline Zinc coat (collector frame) & 1 & 220 & $\mathrm{~m}^{2}$ & 1.2 & 264 & $\mathrm{~m}^{2}$ \\
\hline Electric tracking motor & 1 & 5 & $\mathrm{~kg}$ & 1.2 & 6 & $\mathrm{~kg}$ \\
\hline Tracking mechanism & 1 & 37 & $\mathrm{~kg}$ & 1.2 & 44.4 & $\mathrm{~kg}$ \\
\hline $\begin{array}{l}\text { Tracking mechanism (plastic } \\
\text { (PTFE)) }\end{array}$ & 1 & 0.17 & $\mathrm{~kg}$ & 1.2 & 0.2 & $\mathrm{~kg}$ \\
\hline Mirrors (silver layer) & 1 & 501 & $\mathrm{~kg}$ & 1.2 & 601.2 & $\mathrm{~kg}$ \\
\hline Mirrors (bearing) & 1 & 7.5 & $\mathrm{~kg}$ & 1.2 & 9 & $\mathrm{~kg}$ \\
\hline Absorber & 1 & 137 & $\mathrm{~kg}$ & 1.2 & 164.4 & $\mathrm{~kg}$ \\
\hline Stands and receiver & 1 & 157 & $\mathrm{~kg}$ & 1.2 & 188.4 & $\mathrm{~kg}$ \\
\hline Fixing elements (carbon steel) & 1 & 35 & $\mathrm{~kg}$ & 1.2 & 42 & $\mathrm{~kg}$ \\
\hline \multicolumn{7}{|c|}{ Sensible heat storage } \\
\hline Buffer tank & 1 & 1 & unit & 0.7 & 0.7 & unit \\
\hline \multicolumn{7}{|c|}{ Latent storage } \\
\hline PCM (paraffin) & 1 & 160 & $\mathrm{~kg}$ & 1.5 & 240 & $\mathrm{~kg}$ \\
\hline Aluminum & 1 & 760 & $\mathrm{~kg}$ & 1.5 & 1140 & $\mathrm{~kg}$ \\
\hline \multicolumn{7}{|c|}{ Electric storage } \\
\hline Electric battery & 1 & 108 & $\mathrm{~kg}$ & 0.75 & 81 & $\mathrm{~kg}$ \\
\hline DC-DC converter & 1 & 30 & $\mathrm{~kg}$ & 1.5 & 45 & $\mathrm{~kg}$ \\
\hline AC-DC converter & 1 & 51 & $\mathrm{~kg}$ & 1.5 & 76.5 & $\mathrm{~kg}$ \\
\hline Electric controller & 1 & 0.5 & $\mathrm{~kg}$ & 1.5 & 0.75 & $\mathrm{~kg}$ \\
\hline Current transducer & 3 & 0.09 & $\mathrm{~kg}$ & 1.5 & 0.405 & $\mathrm{~kg}$ \\
\hline Line filter & 1 & 1.35 & $\mathrm{~kg}$ & 1.5 & 2.025 & $\mathrm{~kg}$ \\
\hline Fuses & 6 & 0.015 & $\mathrm{~kg}$ & 1.5 & 0.135 & $\mathrm{~kg}$ \\
\hline Auxiliary power supply & 1 & 0.75 & $\mathrm{~kg}$ & 1.5 & 1.125 & $\mathrm{~kg}$ \\
\hline Grid monitoring & 1 & 0.36 & $\mathrm{~kg}$ & 1.5 & 0.54 & $\mathrm{~kg}$ \\
\hline LED indicators & 5 & 0.05 & $\mathrm{~kg}$ & 1.5 & 0.375 & $\mathrm{~kg}$ \\
\hline Insolation monitoring & 1 & 0.39 & $\mathrm{~kg}$ & 1.5 & 0.585 & $\mathrm{~kg}$ \\
\hline Connectors & 4 & 0.03 & $\mathrm{~kg}$ & 1.5 & 0.18 & $\mathrm{~kg}$ \\
\hline Time delay relay & 1 & 0.07 & $\mathrm{~kg}$ & 1.5 & 0.105 & $\mathrm{~kg}$ \\
\hline Power relay & 1 & 0.645 & $\mathrm{~kg}$ & 1.5 & 0.9675 & $\mathrm{~kg}$ \\
\hline Relays & 5 & 0.045 & $\mathrm{~kg}$ & 1.5 & 0.3375 & $\mathrm{~kg}$ \\
\hline Grid contactors & 1 & 0.63 & $\mathrm{~kg}$ & 1.5 & 0.945 & $\mathrm{~kg}$ \\
\hline DC contactors & 3 & 0.75 & $\mathrm{~kg}$ & 1.5 & 3.375 & $\mathrm{~kg}$ \\
\hline Battery contactor & 1 & 3.9 & $\mathrm{~kg}$ & 1.5 & 5.85 & $\mathrm{~kg}$ \\
\hline Circuit breakers + auxiliaries & 7 & 0.4 & $\mathrm{~kg}$ & 1.5 & 4.2 & $\mathrm{~kg}$ \\
\hline Pre-charge resistor & 1 & 0.01 & $\mathrm{~kg}$ & 1.5 & 0.015 & $\mathrm{~kg}$ \\
\hline Switches & 4 & 0.15 & $\mathrm{~kg}$ & 1.5 & 0.9 & $\mathrm{~kg}$ \\
\hline Smart meter & 1 & 0.3 & $\mathrm{~kg}$ & 1.5 & 0.45 & $\mathrm{~kg}$ \\
\hline Ethernet switch & 1 & 0.28 & $\mathrm{~kg}$ & 1.5 & 0.42 & $\mathrm{~kg}$ \\
\hline Terminal blocks & 84 & 0.01 & $\mathrm{~kg}$ & 1.5 & 1.26 & $\mathrm{~kg}$ \\
\hline Electric cabinet + accessories & 1 & 35 & $\mathrm{~kg}$ & 1.5 & 52.5 & $\mathrm{~kg}$ \\
\hline DIN rail & 6 & 0.6 & $\mathrm{~kg}$ & 1.5 & 5.4 & $\mathrm{~kg}$ \\
\hline Wires & 1 & 22.5 & $\mathrm{~kg}$ & 1.5 & 33.75 & $\mathrm{~kg}$ \\
\hline Screws & 150 & 0.04 & $\mathrm{~kg}$ & 1.5 & 9 & $\mathrm{~kg}$ \\
\hline Nuts & 100 & 0.03 & $\mathrm{~kg}$ & 1.5 & 4.5 & $\mathrm{~kg}$ \\
\hline Washers & 100 & 0.01 & $\mathrm{~kg}$ & 1.5 & 1.5 & $\mathrm{~kg}$ \\
\hline Slotted wiring duct & 3 & 0.5 & $\mathrm{~kg}$ & 1.5 & 2.25 & $\mathrm{~kg}$ \\
\hline Strain relief bar & 5 & 0.01 & $\mathrm{~kg}$ & 1.5 & 0.075 & $\mathrm{~kg}$ \\
\hline \multicolumn{7}{|c|}{ PV panels } \\
\hline PV panels & 1 & 20 & $\mathrm{~m}^{2}$ & 1.2 & 24 & $\mathrm{~m}^{2}$ \\
\hline
\end{tabular}


Table 5. Annual energy consumption of the reference system.

\begin{tabular}{ccc}
\hline Component & Energy Consumption (kWh/Year) & Type of Energy \\
\hline Heat pump & 2198 & Electricity \\
Gas boiler & 10,130 & Gas \\
Circulation pump: solar collectors & 90 & Electricity \\
Circulation pump: heating & 54 & Electricity \\
Total 1 & 2342 & Electricity \\
Total 2 & 10,130 & Gas \\
\hline
\end{tabular}

TRNSYS dynamic simulations were carried out also considering the innovative system connected to the same reference building. This allows us to have an assessment of innovative system behavior and energy consumption of the main system components. Table 6 summarizes the annual energy consumption of the main system components. Comparing the total annual energy consumption of the innovative system with that of the reference system, it can be seen that the innovative system has slightly higher electricity consumption ( $2766 \mathrm{kWh}$ vs. $2342 \mathrm{kWh}$ ) but no gas consumption. This means that a reduction of almost $80 \%$ of the overall energy consumption of the building (electricity + gas) can be achieved using the innovative solution.

Table 6. Annual energy consumption of the innovative system.

\begin{tabular}{ccc}
\hline Component & Energy Consumption (kWh/Year) & Type of Energy \\
\hline Heat pump & $1564^{*}$ & Electricity \\
Dry cooler & 215 & Electricity \\
Adsorption & 80 & Electricity \\
DHW electric heater & 552 & Electricity \\
Circulation pumps & 355 & Electricity \\
Total & 2766 & Electricity \\
\hline
\end{tabular}

${ }^{*}$ Grid electricity contribution to heat pump.

\subsubsection{Impact Assessment of Manufacturing and Disposal Stage}

The LCIA of both the reference and the innovative systems are presented in Tables 7 and 8 , respectively, for the manufacturing and disposal stages.

Table 7. Impact assessment of reference system during manufacturing/disposal stages.

\begin{tabular}{|c|c|c|c|c|}
\hline \multirow{2}{*}{ Element } & Mass Used & ReCiPe & GWP 100a & GWP 20a \\
\hline & (kg) & Impact $/ \mathrm{m}^{2}$ & $\mathrm{kgCO}_{2}-\mathrm{eq} / \mathrm{m}^{2}$ & $\mathrm{kgCO}{ }_{2}-\mathrm{eq} / \mathrm{m}^{2}$ \\
\hline \multicolumn{5}{|c|}{ Solar collector } \\
\hline Solar collector & 118.2 & 3.293 & 2.617 & 3.089 \\
\hline 2-way manual valve & 1.3 & 0.014 & 0.025 & 0.029 \\
\hline Check valve & 4.2 & 0.046 & 0.083 & 0.097 \\
\hline Non-return valve & 1 & 0.004 & 0.008 & 0.010 \\
\hline Piping & 7.7 & 0.032 & 0.065 & 0.074 \\
\hline Insulation (outdoor) & 2.3 & 0.163 & 0.109 & 0.130 \\
\hline \multicolumn{5}{|c|}{ DHW storage tank } \\
\hline Motorized 3-way valve & 12.5 & 0.052 & 0.106 & 0.119 \\
\hline 2-way manual valve & 4.5 & 0.019 & 0.038 & 0.043 \\
\hline Check valve & 4.2 & 0.018 & 0.036 & 0.041 \\
\hline Circulation pump & 2 (unit) & 0.265 & 0.188 & 0.219 \\
\hline Flow rate display/meter & 1.8 & 0.015 & 0.168 & 0.218 \\
\hline Buffer tank & 3 (unit) & 10.134 & 24.611 & 28.768 \\
\hline \multicolumn{5}{|c|}{ Gas boiler } \\
\hline Gas boiler & 1.5 (unit) & 6.435 & 7.649 & 8.960 \\
\hline Piping & 21.3 & 0.089 & 0.180 & 0.203 \\
\hline Insulation (indoor) & 3.8 & 0.270 & 0.180 & 0.216 \\
\hline \multicolumn{5}{|c|}{ Heat pump } \\
\hline Heat pump & 1.5 (unit) & 17.152 & 23.356 & 50.132 \\
\hline 2-way manual valve & 2.2 & 0.009 & 0.019 & 0.021 \\
\hline
\end{tabular}


Table 8. Impact assessment of the innovative system during manufacturing/disposal stages.

\begin{tabular}{|c|c|c|c|c|}
\hline \multirow{2}{*}{ Element } & Mass Used & ReCiPe & GWP 100a & GWP 20a \\
\hline & (kg) & Impact $/ \mathrm{m}^{2}$ & $\mathrm{kgCO}_{2}-\mathrm{eq} / \mathrm{m}^{2}$ & $\mathrm{kgCO}_{2}-\mathrm{eq} / \mathrm{m}^{2}$ \\
\hline \multicolumn{5}{|c|}{ Heat pump } \\
\hline Heat pump & 1.5 (unit) & 16.892 & 22.020 & 48.469 \\
\hline \multicolumn{5}{|c|}{ Sorption module } \\
\hline Adsorber & 140 & 7.907 & 12.166 & 15.163 \\
\hline Evaporator & 72 & 8.030 & 207.522 & 2.314 \\
\hline Bar spacer & 64 & 1.015 & 165.806 & 1.964 \\
\hline Bar spacer (PVC) & 25 & 0.131 & 65.384 & 0.814 \\
\hline Shell & 92 & 1.459 & 238.347 & 2.823 \\
\hline Perforated metal plate & 28 & 0.444 & 72.540 & 0.859 \\
\hline Compensator & 2.4 & 0.038 & 6.218 & 0.074 \\
\hline Sealing & 0.2 & 0.002 & 1.717 & 0.041 \\
\hline Vacuum flange & 0.64 & 0.036 & 5.561 & 0.069 \\
\hline Insulation & 12 & 0.881 & 66.642 & 0.717 \\
\hline Pumps & 30 & 0.271 & 63.202 & 0.747 \\
\hline 3 -way valves & 14.4 & 8.954 & 214.067 & 2.493 \\
\hline Hydraulic tubes & 50 & 5.576 & 144.112 & 1.607 \\
\hline Insulation & 8 & 0.587 & 44.428 & 0.478 \\
\hline Base plate & 125 & 1.982 & 323.841 & 3.836 \\
\hline Frame & 125 & 1.982 & 323.841 & 3.836 \\
\hline Shell & 310 & 4.916 & 8.031 & 9.513 \\
\hline Zeolite & 44 & 0.452 & 2.104 & 2.378 \\
\hline \multicolumn{5}{|c|}{ Dry cooler } \\
\hline System separation unit & 90 & 1.427 & 2.332 & 2.762 \\
\hline Heat exchanger and frame & 1122 & 40.204 & 43.016 & 51.867 \\
\hline Vans & 60 & 0.110 & 1.586 & 1.608 \\
\hline Electric cables & 60 & 6.692 & 172.935 & 1.929 \\
\hline \multicolumn{5}{|c|}{ Fresnel collectors } \\
\hline Collector frame & 1050 & 14.493 & 27.203 & 32.222 \\
\hline Zinc coat (collector frame) & $264\left(\mathrm{~m}^{2}\right)$ & 17.834 & 13.752 & 15.148 \\
\hline Electric tracking motor & 6 & 0.641 & 0.570 & 0.661 \\
\hline Tracking mechanism & 44.4 & 0.704 & 1.150 & 1.363 \\
\hline Tracking mechanism (plastic (PTFE)) & 0.2 & 0.001 & 0.005 & 0.005 \\
\hline Mirrors (silver layer) & 601.2 & 1.145 & 6.681 & 7.255 \\
\hline Mirrors (bearing) & 9 & 0.050 & 0.298 & 0.356 \\
\hline Absorber & 164.4 & 9.285 & 14.286 & 17.806 \\
\hline Stands and receiver & 188.4 & 2.988 & 4.881 & 5.782 \\
\hline Fixing elements (carbon steel) & 42 & 0.666 & 1.088 & 1.289 \\
\hline \multicolumn{5}{|c|}{ Sensible heat storage } \\
\hline Buffer tank & 0.7 (unit) & 2.211 & 5.118 & 5.966 \\
\hline \multicolumn{5}{|c|}{ Latent storage } \\
\hline Paraffin & 240 & 0.597 & 1.600 & 1.708 \\
\hline RPW-HEX & 1140 & 8.570 & 99.062 & 123.471 \\
\hline
\end{tabular}


Table 8. Cont.

\begin{tabular}{|c|c|c|c|c|}
\hline \multirow{2}{*}{ Element } & Mass Used & ReCiPe & GWP 100a & GWP 20a \\
\hline & (kg) & Impact $/ \mathrm{m}^{2}$ & $\mathrm{kgCO}_{2}-\mathrm{eq} / \mathrm{m}^{2}$ & $\mathrm{kgCO}_{2}-\mathrm{eq} / \mathrm{m}^{2}$ \\
\hline \multicolumn{5}{|c|}{ Electric storage } \\
\hline Electric battery & 81 & 6.153 & 5.675 & 6.896 \\
\hline DC-DC converter & 45 & 5.019 & 1.297 & 1.297 \\
\hline AC-DC converter & 76.5 & 8.532 & 2.205 & 2.205 \\
\hline Electric controller & 0.75 & 0.084 & 0.022 & 0.022 \\
\hline Current transducer & 0.405 & 0.045 & 0.012 & 0.012 \\
\hline Line filter & 2.025 & 1.259 & 0.301 & 0.301 \\
\hline Fuses & 0.135 & 0.084 & 0.020 & 0.020 \\
\hline Auxiliary power supply & 1.125 & 0.125 & 0.032 & 0.032 \\
\hline Grid monitoring & 0.54 & 0.060 & 0.016 & 0.016 \\
\hline LED indicators & 0.375 & 0.042 & 0.011 & 0.011 \\
\hline Insolation monitoring & 0.585 & 0.002 & 0.010 & 0.010 \\
\hline Connectors & 0.18 & 0.020 & 0.016 & 0.005 \\
\hline Time delay relay & 0.105 & 0.065 & 0.050 & 0.016 \\
\hline Power relay & 0.9675 & 0.602 & 0.097 & 0.144 \\
\hline Relays & 0.3375 & 0.210 & 0.095 & 0.050 \\
\hline Grid contactors & 0.945 & 0.105 & 0.121 & 0.027 \\
\hline DC contactors & 3.375 & 0.376 & 0.001 & 0.097 \\
\hline Battery contactor & 5.85 & 0.020 & 0.134 & 0.095 \\
\hline Circuit breakers + auxiliaries & 4.2 & 0.468 & 0.067 & 0.121 \\
\hline Pre-charge resistor & 0.015 & 0.002 & 0.062 & 0.001 \\
\hline Switches & 0.9 & 0.560 & 0.125 & 0.134 \\
\hline Smart meter & 0.45 & 0.280 & 1.513 & 0.067 \\
\hline Ethernet switch & 0.42 & 0.261 & 0.156 & 0.062 \\
\hline Terminal blocks & 1.26 & 0.508 & 0.973 & 0.125 \\
\hline Electric cabinet + accessories & 52.5 & 5.855 & 0.259 & 1.513 \\
\hline DIN rail & 5.4 & 0.602 & 0.669 & 0.156 \\
\hline Wires & 33.75 & 3.764 & 0.223 & 0.973 \\
\hline Screws & 9 & 1.004 & 0.065 & 0.259 \\
\hline Nuts & 4.5 & 2.798 & 0.002 & 0.669 \\
\hline Washers & 1.5 & 0.933 & 1.297 & 0.223 \\
\hline Slotted wiring duct & 2.25 & 0.251 & 2.205 & 0.065 \\
\hline Strain relief bar & 0.075 & 0.008 & 0.022 & 0.002 \\
\hline \multicolumn{5}{|c|}{ PV panels } \\
\hline PV panels & $24\left(\mathrm{~m}^{2}\right)$ & 2.549 & 11.289 & 13.386 \\
\hline
\end{tabular}

\subsubsection{Impact Assessment of Operational Stage}

The LCIA of both the reference and the innovative systems are presented in Tables 9 and 10, respectively, for the operational stage.

Table 9. Impact assessment of the reference system during operational stage for 30-years life-span.

\begin{tabular}{|c|c|c|c|c|}
\hline \multirow{2}{*}{ Installation Element } & \multirow{2}{*}{$\begin{array}{c}\text { Total } \\
\text { (kWh/Year) }\end{array}$} & ReCiPe & GWP 100a & GWP 20a \\
\hline & & Impact $/ \mathrm{m}^{2}$ & $\mathrm{kgCO}_{2}-\mathrm{eq} / \mathrm{m}^{2}$ & $\mathrm{kgCO}_{2}-\mathrm{eq} / \mathrm{m}^{2}$ \\
\hline Heat pump & 2198 & 65.640 & 277.958 & 303.125 \\
\hline Gas boiler & 10,130 & 85.471 & 826.817 & 988.944 \\
\hline Circulating pump-solar collectors & 90 & 2.688 & 11.381 & 12.412 \\
\hline Circulating pump-heating & 54 & 1.613 & 6.829 & 7.447 \\
\hline Total (gas) & 10,130 & 85.471 & 826.817 & 988.944 \\
\hline Total (electricity) & 2342 & 69.941 & 296.168 & 322.983 \\
\hline
\end{tabular}


Table 10. Impact assessment of the innovative system during operational stage for a 30-year lifespan.

\begin{tabular}{ccccc}
\hline \multirow{2}{*}{ Installation Element } & \multirow{2}{*}{$\begin{array}{c}\text { Total } \\
\mathbf{( k W h} / \text { Year) }\end{array}$} & ReCiPe & GWP 100a & GWP 20a \\
\cline { 3 - 5 } & $\mathbf{I m p a c t} / \mathbf{m}^{\mathbf{2}}$ & $\mathbf{~ k g C O}_{\mathbf{2}} \mathbf{- e q} / \mathbf{m}^{\mathbf{2}}$ & $\mathbf{~ k g C O}_{\mathbf{2}} \mathbf{- e q} / \mathbf{m}^{\mathbf{2}}$ \\
\hline Heat pump & 1564 & 46.707 & 197.783 & 215.690 \\
Dry cooler & 215 & 6.421 & 27.189 & 29.650 \\
Adsorption & 80 & 2.389 & 10.117 & 11.033 \\
DHW electric heater & 552 & 16.485 & 69.806 & 76.126 \\
Circulating pumps & 355 & 10.602 & 44.893 & 48.958 \\
Total & 2766 & 82.603 & 349.787 & 381.457 \\
\hline
\end{tabular}

\subsection{Uncertainty Analysis}

Despite the fact that most data used in the LCIA are based on information supplied by component manufacturers of the innovative system, the reference values used in this study might be different in a real implementation of the system. Moreover, the reference system considered for comparison purpose is only a hypothetical system intended to be as representative as possible for the building stock in Mediterranean climate regions. Likewise, the energy consumption of both systems, which were used in the operational stage of the LCA, was obtained from simulations of both the building and the systems using standard but also specific component models as well as some simplifying assumptions. Last but not least, the impact factors associated with the use of ReCiPe and GWP, derived from the database Ecoinvent [26], might also be affected by error.

For all the above reasons, it is expected that the results obtained for both systems are affected by different errors. Even though it is not the main focus of this study, an uncertainty analysis of the results was carried out to support the extending of the validity of the conclusions drawn from the results. To achieve it, a constant uncertainty of $20 \%$ of the amount of material or number of units used during the entire lifespan of the systems was assumed, while a constant uncertainty of $10 \%$ was assumed for the impact factors. To simplify the analysis and avoid unnecessary calculations, these uncertainties were only applied to those components that have a relevant contribution to the overall impact of the system. The uncertainty of a specific impact category was obtained using Equation (1) [31]:

$$
U_{R}=\left[\left(\frac{\partial f}{\partial x_{1}} \cdot u_{x_{1}}\right)^{2}+\left(\frac{\partial f}{\partial x_{2}} \cdot u_{x_{2}}\right)^{2}+\cdots+\left(\frac{\partial f}{\partial x_{n}} \cdot u_{x_{n}}\right)^{2}\right]^{1 / 2}
$$

where $U_{R}$ is the uncertainty of the final result, $f\left(x_{1}, \ldots, x_{\mathrm{n}}\right)$ is a function that describes the impact of a given category, $x_{1}, \ldots, x_{\mathrm{n}}$ are the different independent variable (i.e., amount of material or impact factor), and $u_{x_{1}}, \ldots, u_{x_{n}}$ are the uncertainties of the different independent variables. The results of the uncertainty analysis are shown in Figures 6-13 as error bars.

\section{Results and Discussion}

The results are presented for the functional unit $\mathrm{m}^{2}$ of living floor area. Moreover, the results are presented first considering the ReCiPe indicator and then the IPCC GWP indicator. The interpretations of the results of the impact assessment are presented in this section. The results are interpreted demonstrating four aspects: the comparison between the impact scores of the studied systems, the damage categories, the materials' contribution percentage to the total impact score, and the parametric study of the relationship in mass between the PCM and aluminum contained in the latent storage.

\subsection{Comparison between the Studied Systems}

The results using the ReCiPe indicator for both the reference and the innovative systems, for the $\mathrm{FU} \mathrm{m}{ }^{2}$ of living floor, are presented below. The total impact of the reference system is 193 impact points per $\mathrm{m}^{2}$ of living floor, while that of the innovative system 
is 352 impact points (Figure 6). The higher impact of the innovative system is due to its higher complexity.

When evaluating the ReCiPe damage categories (Figure 7), it is clear that the ecosystem quality category is the one that makes the difference between the reference and the innovative system, since the reference system has nearly one-third of the impact points of the innovative system (90 impact points and 232 impact points, respectively).

Going into even more detail, Figure 8 shows that there is one sub-category outstanding, i.e., the urban land occupation. It is interesting to see that within the resources category, the two sub-categories nearly compensate each other; the fossil depletion has a much higher impact in the reference system, while the metal depletion has a higher impact in the innovative system.

Finally, Figure 9 shows the contribution of each life cycle stage to the overall impact. Here, it is interesting to see that the reference system has higher impact during operation (155 impact points) than during the manufacturing and disposal (38 impact points) stages, while in the innovative system, the operational stage has nearly one-third the impact of the manufacturing and disposal stages (83 and 270 impact points, respectively).

When the IPCC GWP 100a indicator is considered, the reference system has a higher overall impact than the innovative system (Figure 10). This is due to the operational stage, for which a value of $1123 \mathrm{~kg} \mathrm{CO}_{2}$ eq. per $\mathrm{m}^{2}$ was obtained for the reference system, far higher than the $350 \mathrm{~kg} \mathrm{CO}_{2}$ eq. per $\mathrm{m}^{2}$ obtained for the innovative system (Figure 11). If the manufacturing and disposal stages are considered for the same indicator (IPCC GWP 100a), the reference system has an impact of about one-fourth of that of the innovative system (59 kg CO 2 eq. per $\mathrm{m}^{2}$ vs. $314 \mathrm{~kg} \mathrm{CO}$ eq. per $\mathrm{m}^{2}$ ). When the IPCC GWP 20a indicator is considered, the reference system still has a higher overall impact than the reference system (Figure 12). The operational stage makes the difference, with an impact of $1312 \mathrm{~kg} \mathrm{CO} 2$ eq. per $\mathrm{m}^{2}$ for the reference system, which is much higher than the value of $381 \mathrm{~kg} \mathrm{CO}_{2}$ eq. per $\mathrm{m}^{2}$ obtained for the innovative system (Figure 13). In the manufacturing and disposal stages, the impact of the reference system is lower than that of the innovative system (96 kg CO 2 eq. per $\mathrm{m}^{2}$ vs. $400 \mathrm{~kg} \mathrm{CO}$ eq. per $\mathrm{m}^{2}$ ), but the difference is not high enough to make the overall impact of the reference system lower than that of the innovative system.

With this indicator, the use of electricity has a very high impact in any studied system, and this is the reason for the high impact of the reference system. The innovative system used less electricity from the grid and more renewable energy, both thermal and electricity.

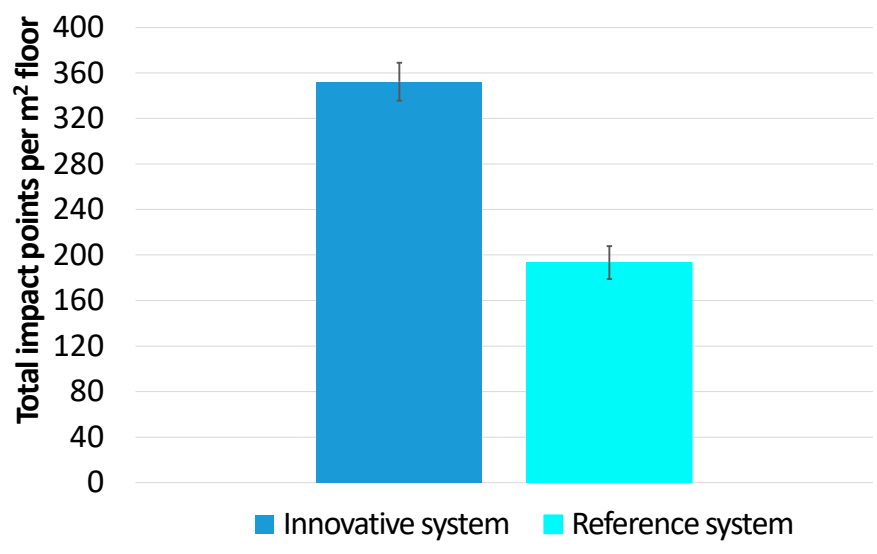

Figure 6. Total impact points per $\mathrm{m}^{2}$ of living floor area using the ReCiPe indicator. 


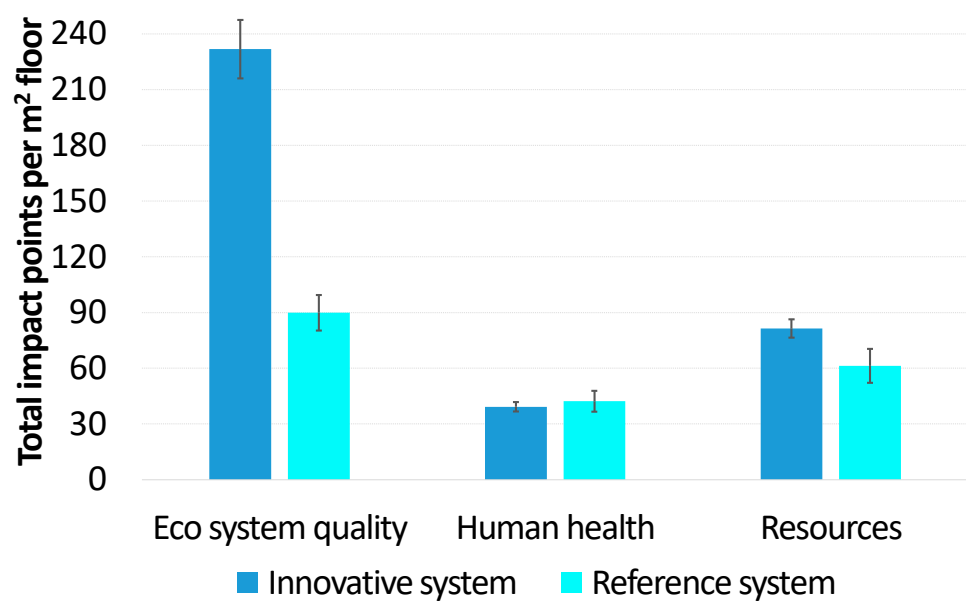

Figure 7. Total impact points of damage categories per $\mathrm{m}^{2}$ of living floor using the ReCiPe indicator.

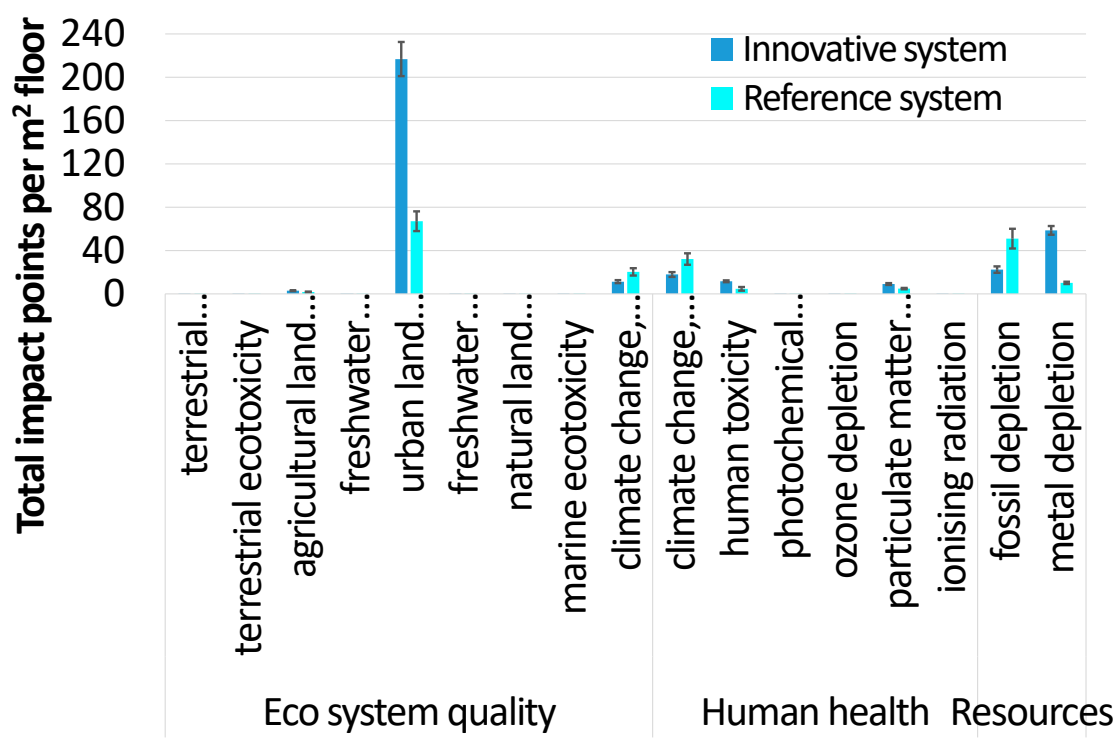

Figure 8. Total impact categories towards ReCiPe endpoint single score.

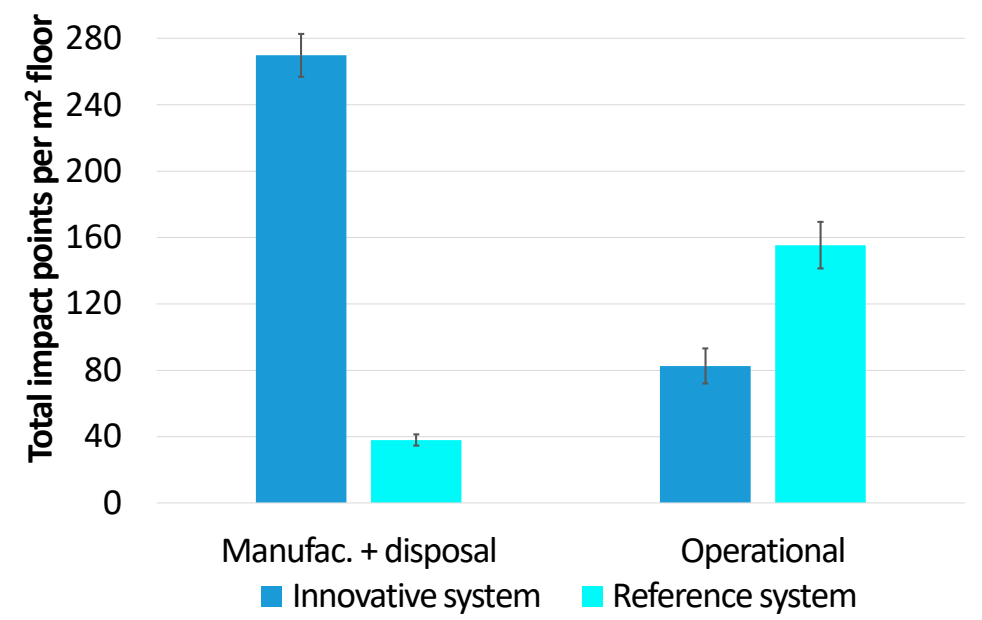

Figure 9. Impact points from the ReCiPe indicator per life cycle stage. 


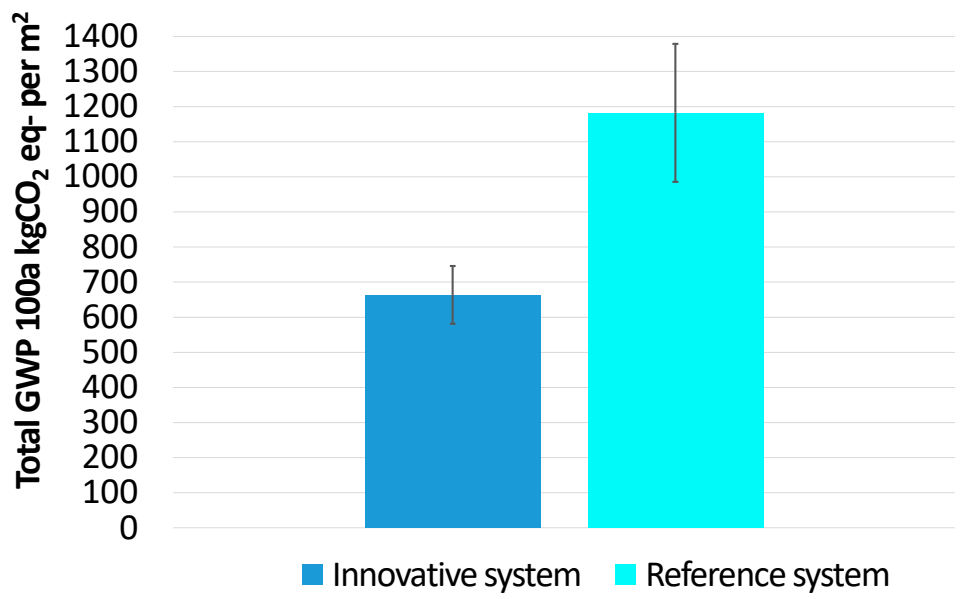

Figure 10. Results per $\mathrm{m}^{2}$ of living floor using the indicator IPCC GWP 100a total.

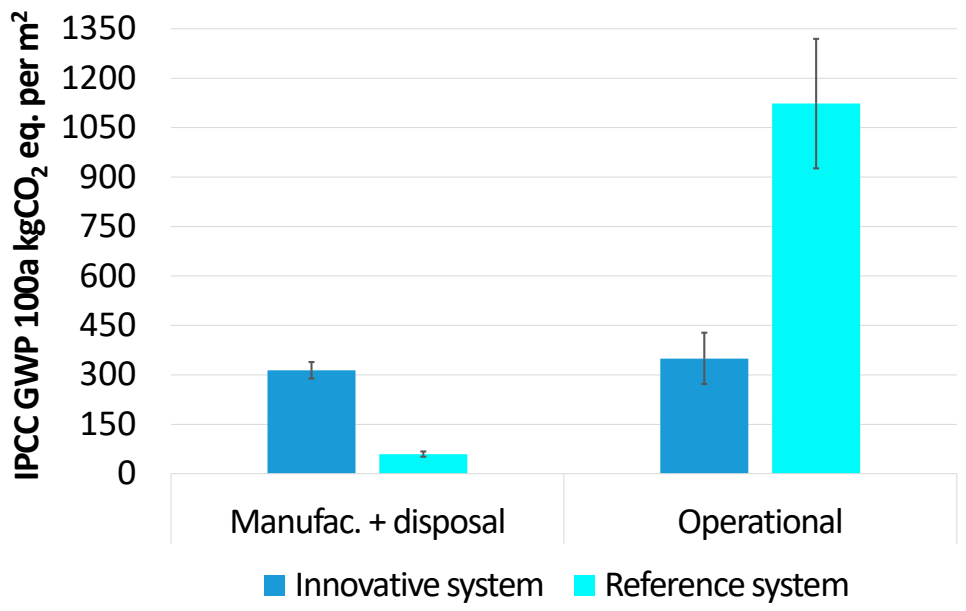

Figure 11. Results per $\mathrm{m}^{2}$ of living floor using the indicator IPCC GWP 100a per life cycle stage.

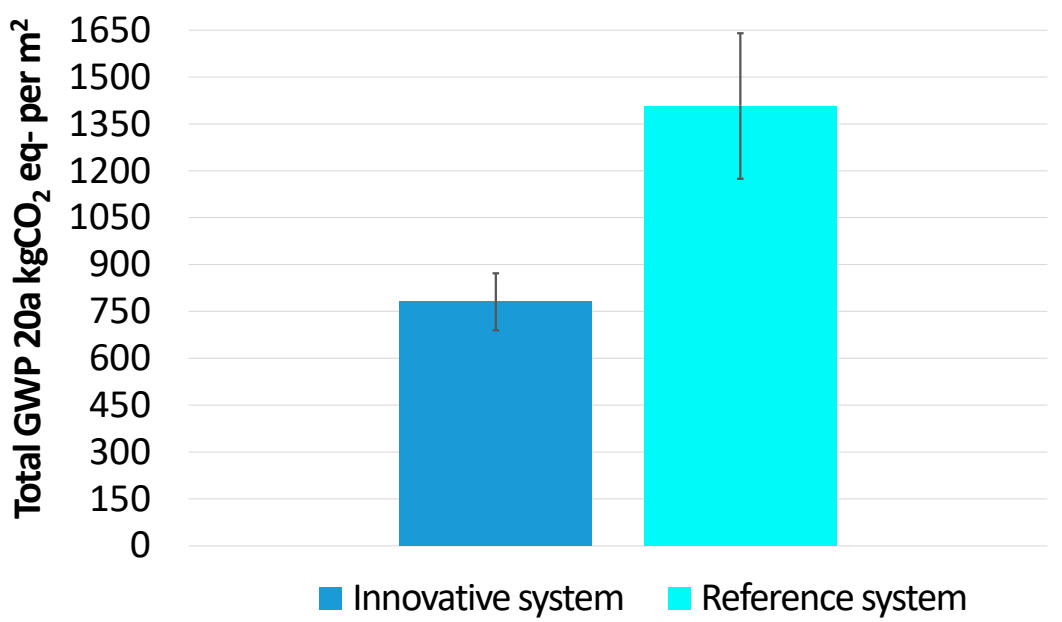

Figure 12. Results per $\mathrm{m}^{2}$ of living floor using the indicator IPCC GWP 20a total. 


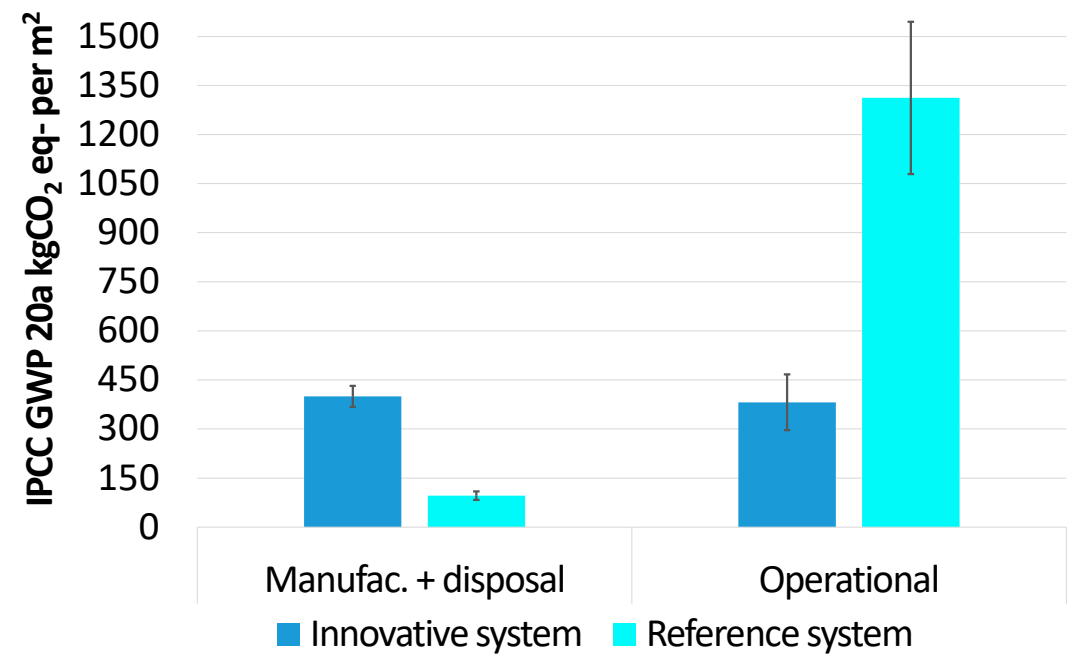

Figure 13. Results per $\mathrm{m}^{2}$ of living floor using the indicator IPCC GWP 20a per life cycle stage.

\subsection{Parametric Study of the Relationship in Mass PCM-Al}

The impact points of the different parts (modules) of the innovative system are shown in Figure 14. The module with highest impact is the latent storage $(29 \%)$, followed by the sorption storage (27\%) and the solar field of Fresnel collectors (21\%). The contribution to the overall impact of the other systems is much lower, i.e., electrical storage (14\%), heat pump (7\%), PV panels (1\%), and sensible heat storage $(1 \%)$.

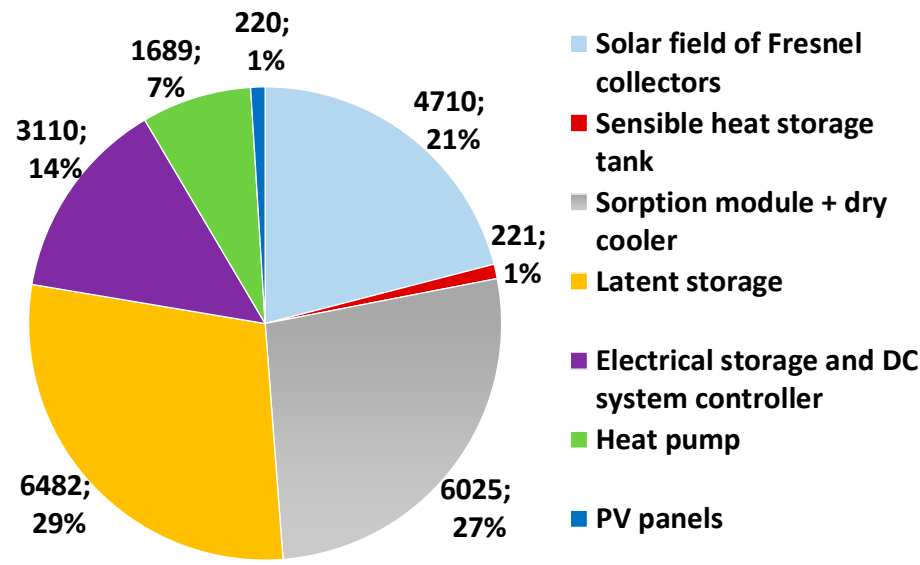

Figure 14. Contribution of each module to the overall innovative system.

Therefore, the low temperature latent heat TES is one of the components with a higher impact; it is also one of the most innovative ones since the configuration used is not common in latent heat storage systems. In this component, the mass relation between aluminum and PCM was identified as having also impacts on its performance [32]. Therefore, the impact of this mass relation in the overall LCA was analyzed. The mass relation between PCM and aluminum in the different latent storage prototypes tested in-laboratory lies between $1 / 3.7$ and 1/5.7. Figure 15 shows the impact when the relation ranges from $1 / 3$ to $1 / 6$ for a constant amount of PCM. This means that only the amount of aluminum is different for different mass relation values. As it can be seen, the higher the mass of aluminum (i.e., the lower the mass ratio), the higher the impact, which can be attributed to the impact of aluminum's manufacturing stage. By doubling the value of this ratio, the relative impact of the latent storage is considerably reduced from $34 \%$ to $21 \%$. Therefore, a suitable design of the latent storage should be aimed at maximizing the mass relationship between PCM and aluminum. This would have other positive effects such as an increase in the energy storage density due to a much higher specific energy storage capacity of the PCM as compared to 
that of aluminum. As a consequence, the weight and volume of the latent storage would be lower for the same energy storage capacity.

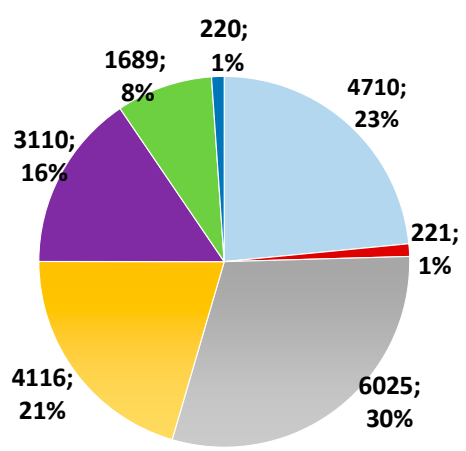

(a)

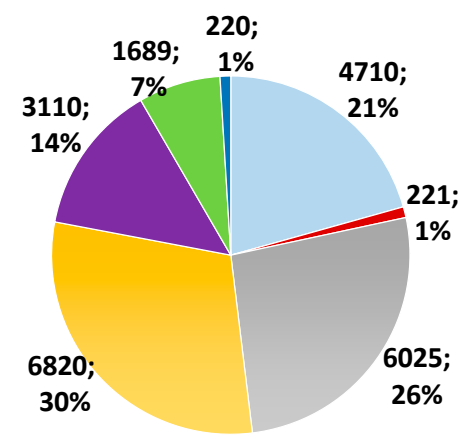

(c)

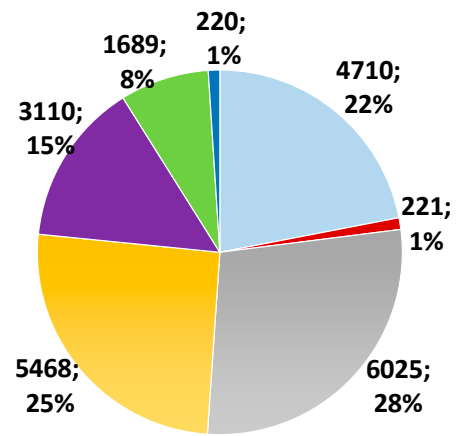

(b)

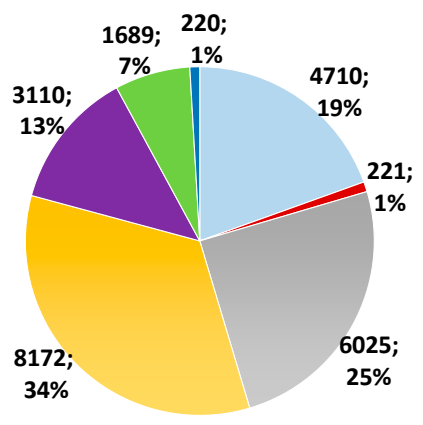

(d)

\section{Solar field of Fresnel collectors \\ - Sensible heat storage tank \\ Sorption module + dry cooler}

Latent storage

- Electrical storage and DC system controller

Heat pump

- PV panels

Figure 15. Relative impact of the main system components for different PCM-Al mass relations. (a) Relation 1/3; (b) relation $1 / 4 ;(\mathbf{c})$ relation $1 / 5 ;(\mathbf{d})$ relation $1 / 6$.

\section{Conclusions}

A detailed LCA was carried out for an innovative system aimed at providing cooling, heating, and domestic hot water (DHW) in residential buildings in Mediterranean climate regions. The LCA was performed comparing the results to a selected standard reference system. The LCA was carried out for a functional unit, $1 \mathrm{~m}^{2}$ of living floor, and two different indicators were used, ReCiPe and IPCC GWP (20 years and 100 years).

The inventory of the systems was carried out collecting data from components manufacturers or using data from the literature. The operational data was obtained through simulations carried out to estimate the energy consumption of both systems using a singlefamily house located in Athens as reference building.

1. When using the ReCiPe indicator:

The overall impact of the innovative system is higher than for the reference system. This is mainly due to the higher complexity of the system;

The damage category with a higher impact is the eco-system quality one, and within this, the urban land occupation withstands among all others;

- When evaluating the life cycle stages, it is clear that for the reference system, the operation has a higher impact than the manufacturing and disposal, while in the innovative system, it is the other way around. This is due to the lower use of electricity from the grid in the innovative system.

2. When using the IPCC GWP indicator:

The overall impact of the innovative system is lower than that of the reference system; In this case, the impact of the operational stage clearly makes the difference, since although in the manufacturing stage the impact of the innovative system 
is higher than that of the reference system, the decrease in the operational stage in the innovative system clearly compensates it.

3. Contribution of the different subsystems:

In the innovative system, the sub-systems with higher contribution in the overall impact are the latent TES system (29\%), the sorption storage $(27 \%)$, and the solar field $(21 \%)$;

The other systems have much lower contribution, i.e., electrical storage (14\%), heat pump (7\%), PV panels (1\%), and sensible heat storage (1\%).

4. Parametric study:

Given that it is the sub-system with a higher contribution to the overall impact and that it also has an impact on the energy performance of the system, the influence of the latent storage sub-system in the overall impact was evaluated; When changing the PCM-aluminum ratio in the storage component (the two materials with higher impact in the energy performance and in the environmental evaluation), the contribution of this sub-system to the overall impact changes from $21 \%$ to $34 \%$, showing that this is a target to study to improve the innovative system.

Overall, the results of this study show that although complex and innovative systems for cooling, heating, and DHW supply may reach high efficiency and achieve a relevant reduction in the energy consumption during the operational stage, the entire life cycle of the system should be considered to assess its real environmental impact. This is because the manufacturing and disposal stages of complex systems may have too high of an environmental impact that could not be compensated by the operational stage. The main limitation of this study is the difficulty of obtaining accurate values of some of the system parameters, such as the amount of material used in some components, or energy consumption in real conditions. Therefore, future research is needed to study the influence of the most impactful parameters' variability through an error propagation analysis using, for instance, a Monte Carlo approach.

Author Contributions: Conceptualization, L.F.C., G.Z. and V.P.; methodology, L.F.C. and N.L.; formal analysis, G.Z.; investigation, N.L., F.T. and V.P.; resources, L.F.C. and A.F.; data curation, L.F.C.; writing-original draft preparation, N.L. and L.F.C.; writing-review and editing, G.Z., V.P., A.F., M.D. and F.T.; visualization, N.L.; supervision, L.F.C.; project administration, L.F.C., A.F. and M.D.; funding acquisition, L.F.C., A.F. and M.D. All authors have read and agreed to the published version of the manuscript.

Funding: This project received funding from the European Union's Horizon 2020 research and innovation programme under grant agreement No 768824 (HYBUILD). This work was partially funded by the Ministerio de Ciencia, Innovación y Universidades de España (RTI2018-093849-B-C31MCIU/AEI/FEDER, UE) and by the Ministerio de Ciencia, Innovación y Universidades-Agencia Estatal de Investigación (AEI) (RED2018-102431-T). The authors would like to thank the Catalan Government for the quality accreditation given to their research group (2017 SGR 1537). GREiA is certified agent TECNIO in the category of technology developers from the Government of Catalonia. This work is partially supported by ICREA under the ICREA Academia programme.

Institutional Review Board Statement: Not applicable.

Informed Consent Statement: Not applicable.

Data Availability Statement: The data presented in this study are openly available in DataverseCat repository (https:/ / dataverse.csuc.cat/, accessed on 15 April 2021) at doi:10.34810/data45.

Acknowledgments: The authors would like to thank all partners that contributed to the inventory (CSEM Centre Suisse d'Electronique et de Microtechnique SA-Recherche et Développement, Daikin Airconditioning Greece S.A., FAHRENHEIT GmbH, Fresnex GmbH, Pink GmbH, AKG Verwaltungsgesellschaft $\mathrm{mbH}$, and National Council or Research Italy, Institute for Advanced Energy Technologies). 
Conflicts of Interest: The authors declare no conflict of interest.

\section{References}

1. International Energy Agency. Global Status Report for Buildings and Construction 2019; International Energy Agency: Paris, France, 2019.

2. Swilling, M.; Robinson, B.; Marvin, S.; Hodson, M.; Hajer, M. City-Level Decoupling: Urban Resource Flows and the Governance of Infrastructure Transitions. A Report of the Working Group on Cities of the International Resource Panel; United Nations Environment Programme (UNEP): Nairobi, Kenya, 2013.

3. Eurostat. Smarter, Greener, More Inclusive? Indicators to Support the Europe 2020 Strategy; Eurostat: Luxembourg, 2018. [CrossRef]

4. United Nations. United Nations Development Programme. Goal 12: Responsible Consumption and Production 2020. Available online: www.undp.org/content/undp/en/home/sustainable-development-goals/goal-12-responsible-consumption-andproduction.html (accessed on 15 April 2021).

5. Guinee, J.B. Handbook on life cycle assessment operational guide to the ISO standards. Int. J. Life Cycle Assess. 2002, 7, 311-313. [CrossRef]

6. Pérez-Lombard, L.; Ortiz, J.; Pout, C. A review on buildings energy consumption information. Energy Build. 2008, 40, 394-398. [CrossRef]

7. Soares, N.; Bastos, J.; Pereira, L.D.; Soares, A.; Amaral, A.; Asadi, E.; Rodrigues, E.; Lamas, F.; Monteiro, H.; Lopes, M.; et al A review on current advances in the energy and environmental performance of buildings towards a more sustainable built environment. Renew. Sustain. Energy Rev. 2017, 77, 845-860. [CrossRef]

8. Germani, M.; Landi, D.; Rossi, M. Efficiency and Environmental Analysis of a System for Renewable Electricity Generation and Electrochemical Storage of Residential Buildings. Procedia CIRP 2015, 29, 839-844. [CrossRef]

9. Mousa, O.B.; Kara, S.; Taylor, R.A. Comparative energy and greenhouse gas assessment of industrial rooftop-integrated PV and solar thermal collectors. Appl. Energy 2019, 241, 113-123. [CrossRef]

10. Goel, V.; Bhat, I.; Prakash, R. LCA of renewable energy for electricity generation systems-A review. Renew. Sustain. Energy Rev. 2009, 13, 1067-1073. [CrossRef]

11. Raluy, R.G.; Serra, L.M.; Guadalfajara, M.; Lozano, M.A. Life Cycle Assessment of Central Solar Heating Plants with Seasonal Storage. Energy Procedia 2014, 48, 966-976. [CrossRef]

12. Bartolucci, L.; Cordiner, S.; Mulone, V.; Pasquale, S.; Santarelli, M. Hybrid renewable energy systems: Impact of thermal storage on systems optimal design and performance. In AIP Conference Proceedings; AIP Publishing LLC: Melville, NY, USA, 2019 ; p. 020016.

13. Kyriaki, E.; Konstantinidou, C.; Giama, E.; Papadopoulos, A.M. Life cycle analysis (LCA) and life cycle cost analysis (LCCA) of phase change materials (PCM) for thermal applications: A review. Int. J. Energy Res. 2018, 42, 3068-3077. [CrossRef]

14. de Gracia, A.; Rincón, L.; Castell, A.; Jiménez, M.; Boer, D.; Medrano, M.; Cabeza, L.F. Life Cycle Assessment of the inclusion of phase change materials (PCM) in experimental buildings. Energy Build. 2010, 42, 1517-1523. [CrossRef]

15. Castell, A.; Menoufi, K.; de Gracia, A.; Rincón, L.; Boer, D.; Cabeza, L.F. Life Cycle Assessment of alveolar brick construction system incorporating phase change materials (PCMs). Appl. Energy 2013, 101, 600-608. [CrossRef]

16. De Gracia, A.; Navarro, L.; Castell, A.; Boer, D.; Cabeza, L.F. Life cycle assessment of a ventilated facade with PCM in its air chamber. Sol. Energy 2014, 104, 115-123. [CrossRef]

17. Aranda-Usón, A.; Ferreira, G.; López-Sabirón, A.M.; Mainar-Toledo, M.; Bribián, I.Z. Phase change material applications in buildings: An environmental assessment for some Spanish climate severities. Sci. Total Environ. 2013, 444, 16-25. [CrossRef] [PubMed]

18. Longo, S.; Palomba, V.; Beccali, M.; Cellura, M.; Vasta, S. Energy balance and life cycle assessment of small size residential solar heating and cooling systems equipped with adsorption chillers. Sol. Energy 2017, 158, 543-558. [CrossRef]

19. Palomba, V.; Varvagiannis, E.; Karellas, S.; Frazzica, A. Hybrid Adsorption-Compression Systems for Air Conditioning in Efficient Buildings: Design through Validated Dynamic Models. Energies 2019, 12, 1161. [CrossRef]

20. Palomba, V.; Dino, G.E.; Frazzica, A. Coupling sorption and compression chillers in hybrid cascade layout for efficient exploitation of renewables: Sizing, design and optimization. Renew. Energy 2020, 154, 11-28. [CrossRef]

21. Dallapiccola, M.; Trentin, F.; Barchi, G.; Dipasquale, C.; Fedrizzi, R.; Moser, D. Machine Learning Driven Optimization of a Hybrid Electrical and Thermal System. In Proceedings of the 37th European Photovoltaic Solar Energy Conference and Exhibition, Lisboa, Portugal, 7-11 September 2020; pp. 1820-1825. [CrossRef]

22. Karasu, H.; Dincer, I. Life cycle assessment of integrated thermal energy storage systems in buildings: A case study in Canada. Energy Build. 2020, 217, 109940. [CrossRef]

23. Llantoy, N.; Chàfer, M.; Cabeza, L.F. A comparative life cycle assessment (LCA) of different insulation materials for buildings in the continental Mediterranean climate. Energy Build. 2020, 225, 110323. [CrossRef]

24. ISO 14040:2006(en). Environmental Management-Life Cycle Assessment-Principles and Framework n.d; ISO: Geneva, Switzerland, 2006.

25. ISO 14044:2006(en). Environmental Management_Life Cycle Assessment-Requirements and Guidelines n.d; ISO: Geneva, Switzerland, 2006.

26. Frischknecht, R.; Jungbluth, N.; Althaus, H.-J.; Doka, G.; Dones, R.; Heck, T.; Hellweg, S.; Hischier, R.; Nemecek, T.; Rebitzer, G.; et al. The ecoinvent Database: Overview and Methodological Framework (7 pp). Int. J. Life Cycle Assess. 2004, 10, 3-9. [CrossRef] 
27. National Institute for Public Health and the Environment. ReCiPe 2016. Available online: https://www.rivm.nl/bibliotheek/ rapporten/2016-0104.pdf (accessed on 9 May 2021).

28. ReCiPe. Available online: https://www.rivm.nl/en/life-cycle-assessment-lca/recipe (accessed on 9 May 2021).

29. Petrovic, B.; Myhren, J.A.; Zhang, X.; Wallhagen, M.; Eriksson, O. Life Cycle Assessment of Building Materials for a Single-family House in Sweden. Energy Procedia 2019, 158, 3547-3552. [CrossRef]

30. Asdrubali, F.; Baldassarri, C.; Fthenakis, V. Life cycle analysis in the construction sector: Guiding the optimization of conventional Italian buildings. Energy Build. 2013, 64, 73-89. [CrossRef]

31. Holman, J. Experimental Methods for Engineers, 8th ed.; MacGraw-Hill: New York, NY, USA, 2012.

32. Mselle, B.D.; Vérez, D.; Zsembinszki, G.; Borri, E.; Cabeza, L.F. Performance Study of Direct Integration of Phase Change Material into an Innovative Evaporator of a Simple Vapour Compression System. Appl. Sci. 2020, 10, 4649. [CrossRef] 